\title{
Eksplorasi Geolistrik Daerah Sulit Air di Desa Plangkapan, Kecamatan Tambak, Kabupaten Banyumas, Provinsi Jawa Tengah
}

\author{
Wahju Krisna Hidajat ${ }^{1}$, Thomas Triadi Putranto ${ }^{1}$, Rinal Khaidar Ali $^{1 *}$ \\ ${ }^{1}$ Departemen Teknik Geologi, Fakultas Teknik, Universitas Diponegoro, Semarang
}

\begin{abstract}
Abstrak
Seiring dengan dengan perkembangan industri, kepadatan pemukiman penduduk, kuantitas dan kualitas air semakin menurun, sedangkan kebutuhan akan air semakin meningkat. Hal tersebut menjadikan bencana bagi manusia yang lebih dikenal sebagai bencana kekeringan. Desa Plangkapan, Kecamatan Tambak, Kabupaten Banyumas, Provinsi Jawa Tengah merupakan daerah yang termasuk pada daerah yang mengalami kekeringan. Oleh karena itu perlu adanya solusi untuk mengentaskan bencana tersebut. Salah satunya adalah dengan mencari lapisan akuifer tempat menampung air tanah. Penelitian ini menggunakan metoda geolistrik Schlumberger Vertical Electrical Sounding (VES). Setelah diperoleh data yang diambil di lapangan, maka dilakukan pengolahan data dengan software Progress ver.3 yang secara otomatis menentukan model resistivitas bawah permukaan dari data hasil pengukuran geolistrik. Berdasarkan pendugaan geolistrik yang telah dilakukan, maka dapat diketahui bahwa ketebalan akuifer berkisar antara 10,9-18,7 m. Kedalaman akuifer berkisar antara 34,5-50,2 m.
\end{abstract}

Kata kunci: Akuifer; Banyumas; geolistrik; kekeringan; Plangkapan.

\begin{abstract}
Along with industrial development, the density of human settlements, the quantity and quality of water has decreased, while the need for water has increased. This makes a disaster for humans which is better known as a drought disaster. Plangkapan Village, Tambak District, Banyumas Regency, Central Java Province is an area that is one of the areas experiencing drought. Therefore, it is necessary to have a solution to alleviate this disaster. One way is to find an aquifer layer to collect groundwater. This study uses the Schlumberger Vertical Electrical Sounding (VES) geoelectric method. After obtaining the data taken in the field, the data processing is carried out with Progress ver.3 software which automatically determines the subsurface resistivity model from the geoelectric measurement data. Based on the geoelectric estimation that has been carried out, it can be seen that the aquifer thickness ranges from 10.9-18.7 m. Meanwhile, the aquifer depth ranges from 34.5-50.2 m.
\end{abstract}

Keywords: Aquifer; Banyumas; resistivity sounding; drought; Plangkapan.

\footnotetext{
*Korespondensi: rinal.khaidarali@gmail.com

Diajukan : 19 Desember 2020

Diterima : 27 Januari 2021

Diterbitkan : 31 Maret 2021
} 


\section{PENDAHULUAN}

Air merupakan kebutuhan manusia yang sangat vital, baik untuk keperluan rumah tangga, industri maupun pertanian. Salah satu pentingnya air bagi manusia adalah kegunaan air sebagai salah satu zat mikro yang mempunyai fungsi penting seperti metabolisme, pengangkutan dan sirkulasi zat gizi dan non gizi, pengendalian suhu tubuh, kontraksi otot, transmisi impuls saraf, pengaturan keseimbangan elektrolit dan proses pembuangan zat tak berguna bagi tubuh (Santoso dkk, 2011). Sedangkan bagi fungsi air pada industri adalah sebagai sumber energi, sumber perpindahan panas, pengangkut bahan dasar, aksi mekanik/penghilang scaling pada alat dan sebagai produk seperti pada industri desalinasi (Widarti, 2015).

Sejalan dengan perkembangan industri, kepadatan pemukiman penduduk dan rendahnya kesadaran masyarakat tentang pengelolaan limbah saat ini, menyebabkan kuantitas dan kualitas air berkurang (Amsyari, 1996). Melihat dari ketergantungan manusia akan air, kekurangan air dari segi kuantitas menjadikan masalah besar bagi keberlangsungan hidup manusia. Kekeringan yang menjadi salah satu faktor kurangnya pasokan air bagi manusia sekarang ini dikategorikan sebagai bencana bagi manusia. Kekeringan dapat didefinisikan sebagai ketersediaan air yang jauh di bawah kebutuhan air untuk kebutuhan hidup, pertanian, kegiatan ekonomi dan lingkungan (Hastuti dkk., 2017). Kekeringan juga dapat dikaitkan dengan kekurangan curah hujan dalam periode waktu tertentu yang berpengaruh terhadap besarnya aliran permukaan pada suatu daerah aliran sungai atau wadah penampung air permukaan lain seperti danau atau telaga (Indarto dkk., 2014).

Badan Koordinasi Nasional Penanggulangan Bencana (Bakornas PB) (2007) dalam Savitri dan Pramono (2018) membedakan kekeringan berdasarkan tipenya menjadi 3 (tiga); yaitu kekeringan, meteorologis, kekeringan pertanian dan kekeringan hidrologis. Kekeringan meteorologis menunjukkan curah hujan dalam satu musim yang berada di bawah normal. Kekeringan pertanian terjadi setelah kekeringan meteorologis, dimana kandungan air dalam tanah tidak mencukupi kebutuhan tanaman pada suatu periode tertentu dan cakupan wilayah yang luas. Kekeringan hidrologis terjadi apabila terdapat penurunan air di waduk, muka air sungai, danau dan muka air tanah secara alami.

Lebih dari 98\% dari semua air di daratan tersembunyi di bawah permukaan tanah dalam pori-pori tanah dan bahan-bahan butiran (air tanah). Dua persen sisanya terlihat sebagai air di sungai, danau dan reservoir (air permukaan) (Rejekiningrum, 2009). Sehingga dalam masa kekeringan yang cenderung diukur dari berkurangnya pasokan air permukaan, manusia dapat memanfaatkan keberadaan air tanah sebagai pemasok kebutuhan air.

Desa Plangkapan, Kecamatan Tambak, Kabupaten Banyumas, Provinsi Jawa Tengah merupakan daerah yang termasuk pada daerah yang mengalami kekeringan (Pemerintah Kabupaten Banyumas, 2009). Terjadinya kekeringan di berbagai wilayah, hilangnya banyak sumber mata air di wilayah perdesaan, turunnya muka air tanah, turunnya debit air sungai dan mata air. Tercatat juga warga di Desa Plangkapan, Kecamatan Tambak belum mengoptimalkan air tanah sebagai sumber air bersih. Melihat dari permasalahan tersebut, maka penelitian ini bertujuan untuk menduga keberadaan akuifer (ketebalan dan kedalaman akuifer) sebagai zona penyimpan air tanah di Desa Plangkapan, Kecamatan Tambak, Kabupaten Banyumas, Provinsi Jawa Tengah. Pendugaan keberadaan akuifer tersebut menggunakan metoda geolistrik Schlumberger Vertical Electrical Sounding (VES).

\section{METODOLOGI}

Metode yang digunakan dalam penelitian ini adalah dengan melakukan survei dan pengukuran data primer di lapangan, serta didukung oleh data sekunder yang telah ada. Salah satu metode yang digunakan dalam penelitian ini adalah metode geolistrik (Schlumberger Vertical Electrical Sounding Method) untuk menduga kondisi geologi bawah permukaan, khususnya macam dan sifat batuan berdasarkan sifat-sifat tahanan jenis (resistivity) (Gambar 1). Konfigurasi Schlumberger ini dilakukan dengan cara mengukur besarnya kuat arus dan beda potensial dengan jarak elektroda yang berbeda (Setiono dkk., 2014).

Pengukuran geolistrik dilakukan sebanyak 3 (tiga) titik dengan bentangan ratarata $400 \mathrm{~m}$. Setelah diperoleh data yang diambil di lapangan, maka dilakukan 
pengolahan data. Pengolahan data geolistrik menggunakan software Progress ver.3. Progress ver.3 adalah program yang secara otomatis menentukan model resistivitas bawah permukaan dari data hasil pengukuran geolistrik. Setelah pengolahan tersebut dilakukan maka dilanjutkan ke tahap pembuatan model 3 dimensi titik-titik sounding (geolistrik) untuk mengetahui secara pasti keberadaan akuifer.

\section{HASIL}

Pendugaan geolistrik di Desa Plangkapan, Kecamatan Tambak, Kabupaten Banyumas, Provinsi Jawa Tengah dilakukan pada 3 (tiga) titik (Tabel 1) (Gambar 2). Titik tersebut ditentukan dari jarak terdekat dengan pemukiman, sehingga bila nantinya akan dibangun konstruksi sumur dalam ataupun dangkal masyarakat tidak terlalu jauh dalam mengakses air tersebut.

Hasil pengolahan data geolistrik dengan menggunakan Progress ver. 3 diperlihatkan pada Gambar 2 dan Gambar 3. Berdasarkan hasil tersebut dan nilai resistivitasnya, maka dapat dibuat Tabel 2. yang merupakan rangkuman hasil pengolahan, analisis, dan interpretasi, sekaligus menunjukkan kedalaman akuifer pada 3 titik amat.

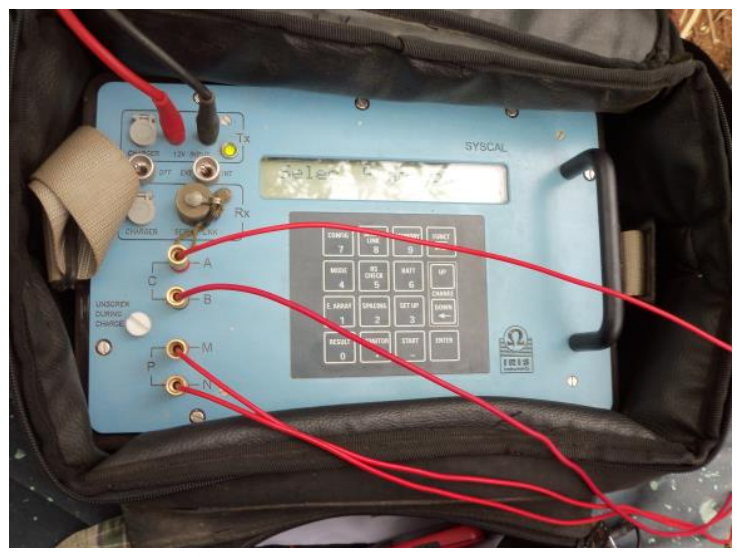

Gambar 1. Alat geolistrik

Tabel 1. Koordinat titik geolistrik (dalam UTM)

\begin{tabular}{ccc}
\hline Titik & X & Y \\
\hline Plangkapan1 & 321630 & 9156901 \\
Plangkapan2 & 321718 & 9156449 \\
Plangkapan3 & 321728 & 9155616 \\
\hline
\end{tabular}

Tabel 2. Hasil analisis dan interpretasi titik sounding di Desa Plangkapan, Kecamatan Tambak.

\begin{tabular}{ccccl}
\hline Titik Amat & $\begin{array}{c}\text { Kedalaman } \\
\text { (meter) }\end{array}$ & $\begin{array}{c}\text { Tebal } \\
\text { (meter) }\end{array}$ & $\begin{array}{c}\text { Nilai rho } \\
\text { (ohm meter) }\end{array}$ & \multicolumn{1}{c}{ Keterangan } \\
\hline Plangkapan1 & 0,00 & 0,48 & 38,09 & Tanah (Soil) \\
& 0,48 & 7,62 & $8,8-10,0$ & Pasir Lempungan \\
& 8,1 & 42,1 & $2,0-6,3$ & Lempung \\
& 50,2 & 27,6 & 10,9 & Pasir (Akuifer) \\
& 77,8 & - & $2,7-4,7$ & Lempung \\
Plangkapan2 & 0,00 & 0,41 & 26,02 & Tanah (Soil) \\
& 0,41 & 3,69 & $9,5-12,6$ & Pasir Lempungan \\
& 4,1 & 34,5 & $1,2-2,2$ & Lempung \\
& 38,6 & 4,6 & 18,7 & Pasir (Akuifer) \\
& 43,2 & - & $0,6-2,0$ & Lempung \\
Plangkapan3 & 0,00 & 0,45 & 66,4 & Tanah (Soil) \\
& 0,45 & 1,35 & 15,1 & Pasir Lempungan \\
& 1,8 & 32,7 & $0,7-5,8$ & Lempung \\
& 34,5 & 13 & 18,3 & Pasir (Akuifer) \\
& 47,5 & - & $0,7-2,7$ & Lempung \\
\hline
\end{tabular}




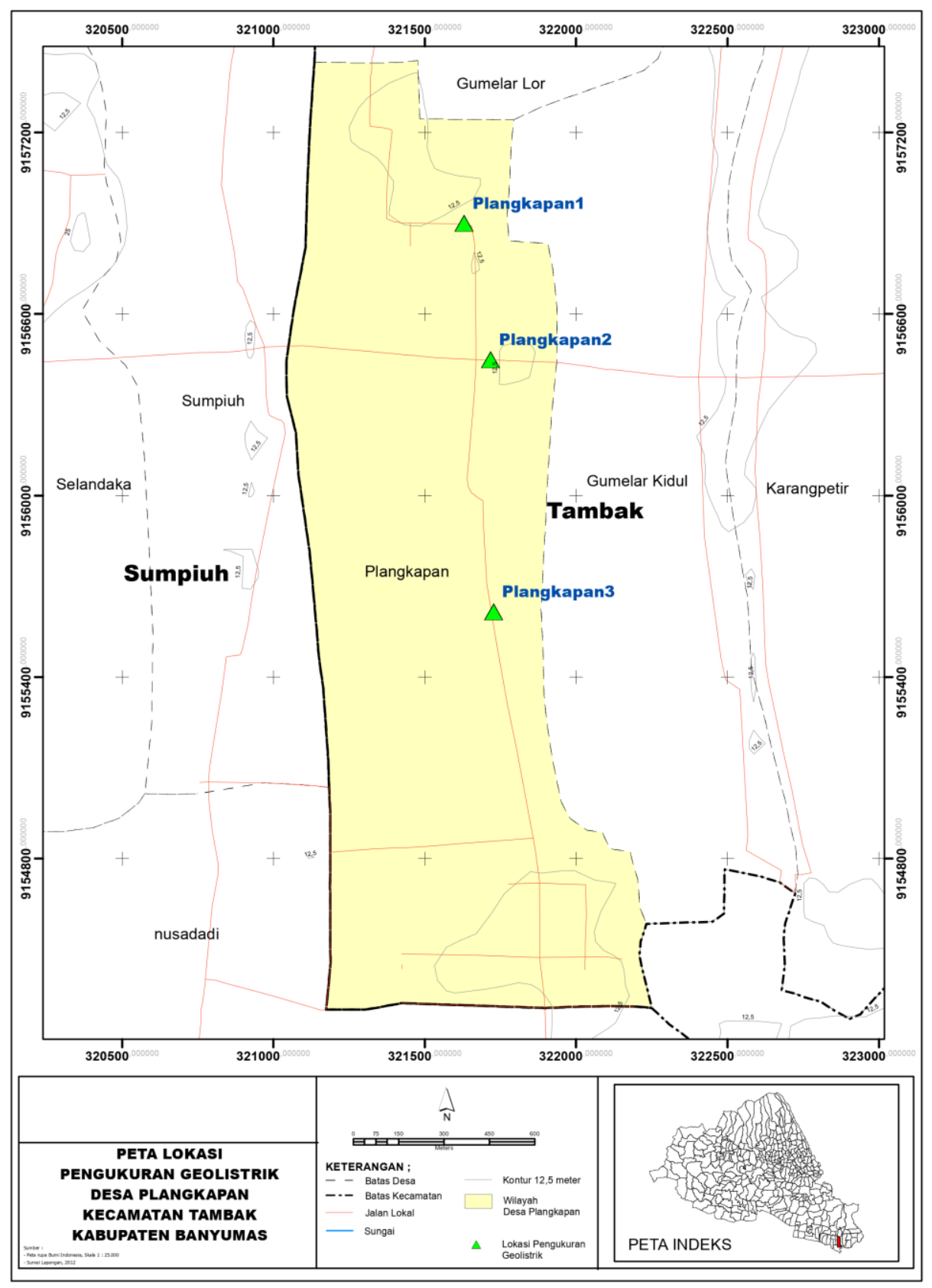

Gambar 2. Peta lokasi pengukuran geolistrik di daerah penelitian 


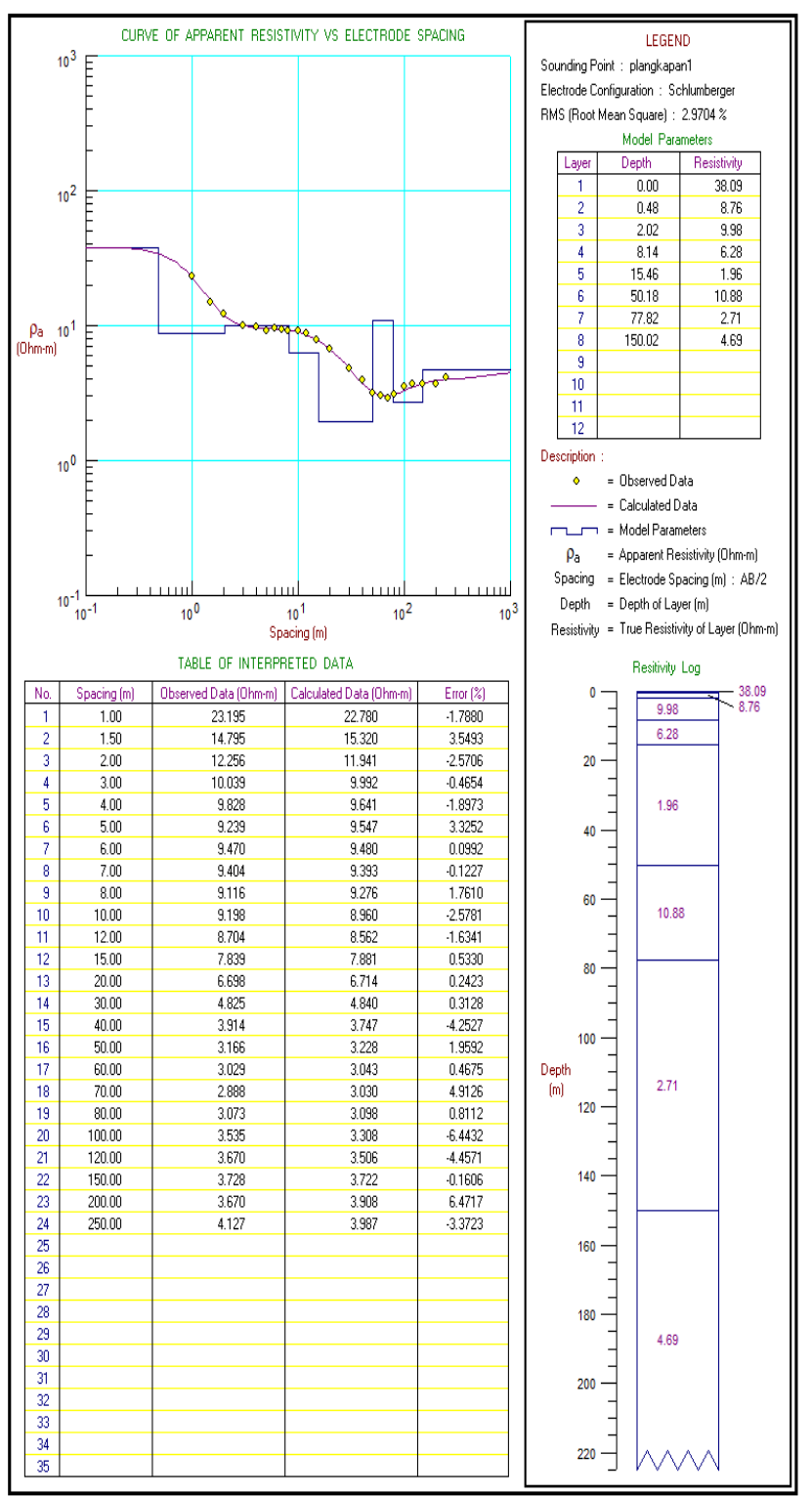

(a)

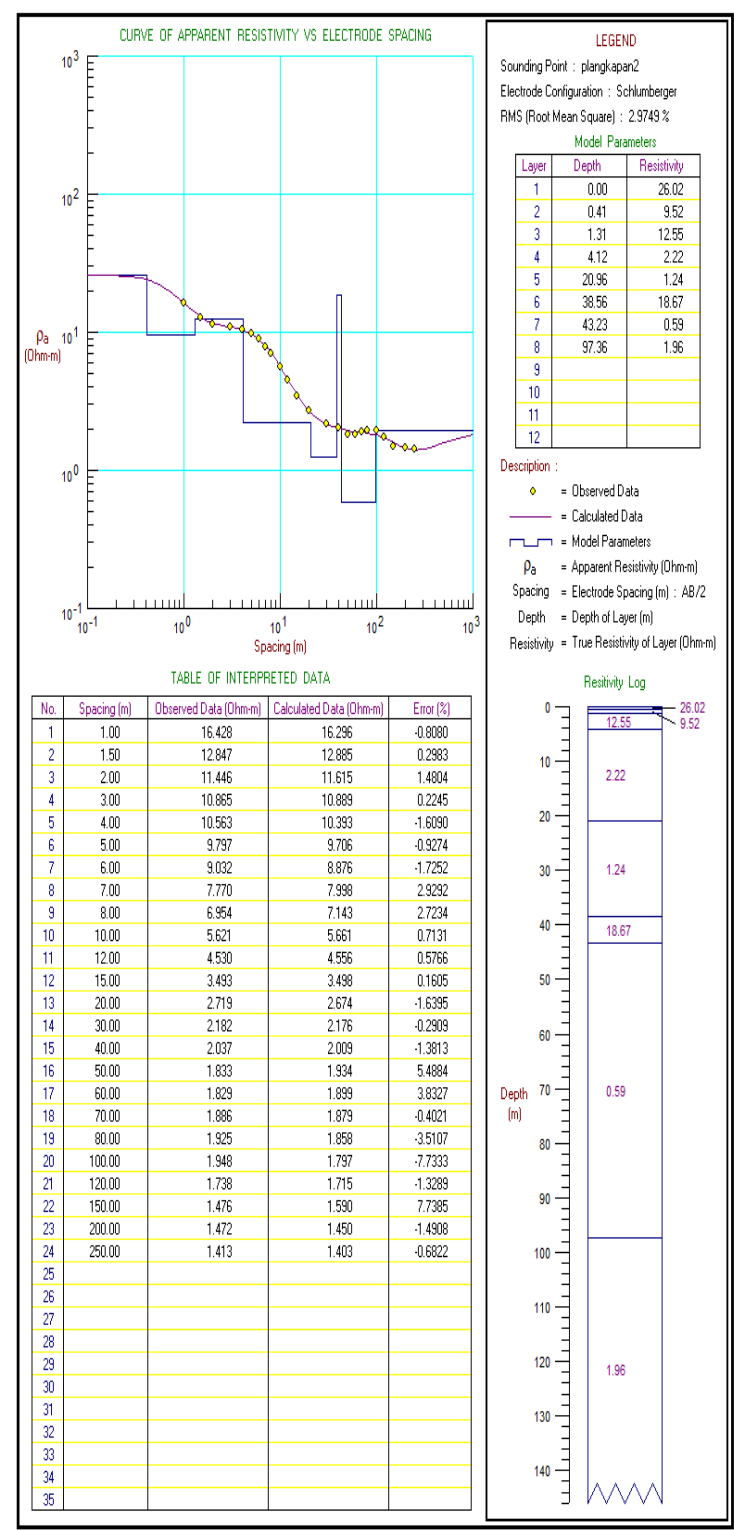

(b)

Gambar 2. Hasil pengolahan data dengan Progress ver.3 untuk (a) titik Plangkapan1, (b) titik Plangkapan2. 


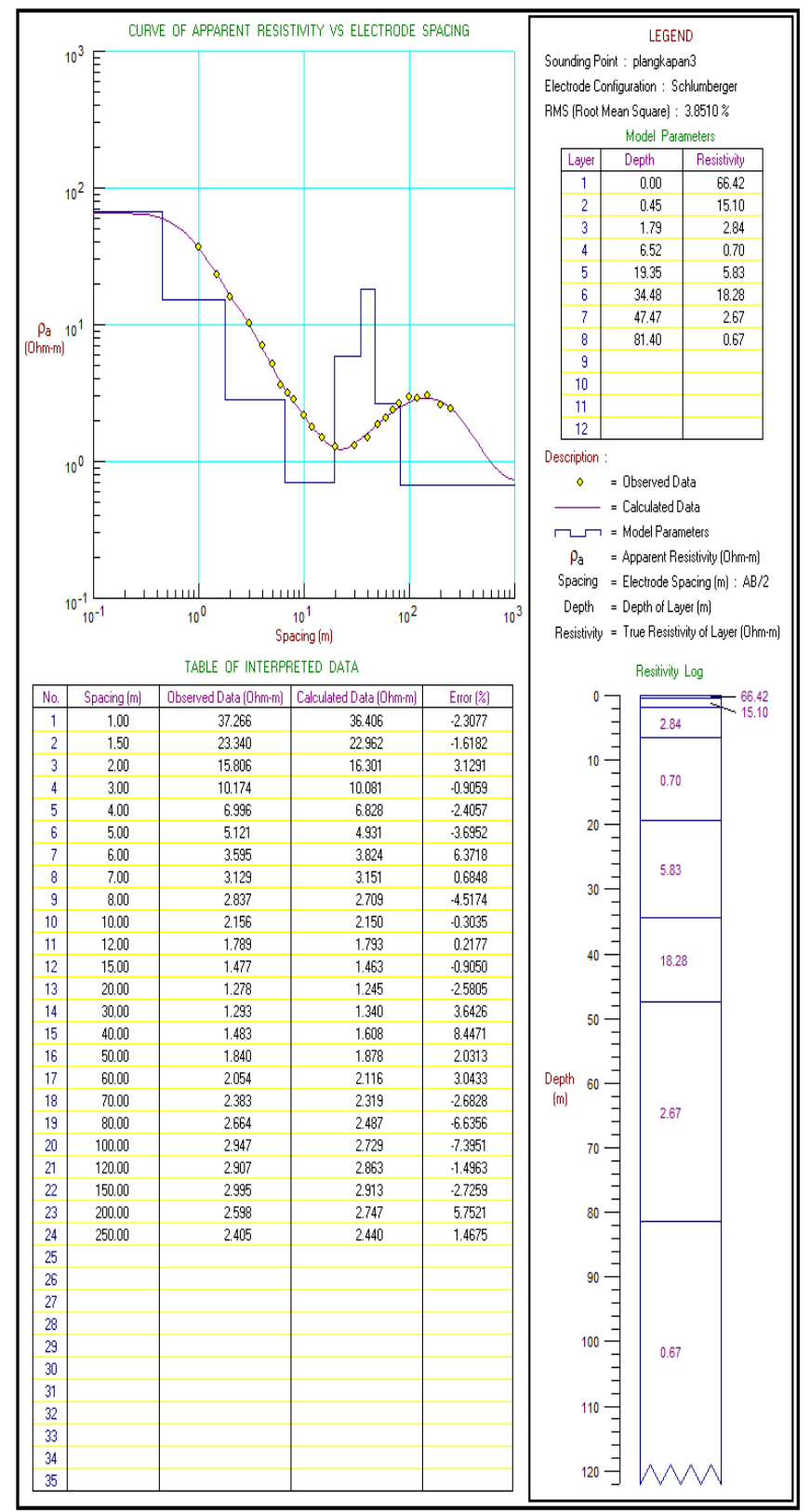

Gambar 3. Hasil pengolahan data dengan Progress ver.3 untuk titik Plangkapan3. 


\section{PEMBAHASAN}

Berdasarkan hasil dari pengolahan data geolistrik, maka di Desa Plangkapan, Kecamatan Tambak, Kabupaten Banyumas terdapat tiga jenis litologi/material yang dapat dideteksi oleh alat geolistrik. Litologi/material tersebut adalah tanah (soil), lempung, pasirl dan pasir.

\section{Tanah (Soil)}

Secara faktor pembetukannya, tanah (soil) dibagi menjadi 2 (dua) yaitu tanah residu dan tanah transport. Tanah residu (residual soils) adalah tanah yang dibentuk oleh pelapukan fisika maupun kimia dari batuan induknya dan belum dipindahkan dari tempatnya. Karakteristik tanah residu sangat bergantung pada sifat-sifat batuan induknya. Apabila tanah hasil pelapukan tersebut dipindahkan dan diendapkan di tempat lain, misalnya oleh air atau angin, maka tanah tersebut dikenal sebagai tanah transport (transported soils) (Sudarsono dan Hasibuan, 2011).

Tanah bersifat lepasan dan belum terlitifikasi. Sehingga tanah belum bisa dikatakan sebagai batu dan belum memiliki pori-pori. Oleh sebab itu tanah (soil) tidak mungkin menjadi sarana akuifer (lapisan penyimpan air).

\section{Lempung}

Lempung (clay) dapat diartikan sebagai bagian dari tanah yang sebagian besar terdiri dari partikel mikroskopis dan submikroskopis (tidak dapat dilihat dengan jelas bila hanya dengan mikroskopis biasa) yang berbentuk lempengan-lempengan pipih dan merupakan partikel-pertikel dari mika, mineralmineral lempung (clay minerals), dan mineral-mineral yang sangat halus lain. Lempung membentuk gumpalan keras saat kering dan lengket apabila basah terkena air dan memiliki sifat elastis yang kuat (Das, 1985). Sedangkan menurut Wentworth (1922), lempung dapat diartikan sebagai material asal batuan yang memiliki ukuran kurang dari 1/256 mm.

Lempung dengan ukurannya yang sangat halus mempunyai rongga antar butiran yang sempit atau kecil, sehingga semakin lambat pula air mengalir dalam lapisan lempung tersebut atau bias dikatakan permeabilitas lempung sangat kecil. Oleh karena itu pada lempung, kecepatan air mengalir relatif lebih lambat
(Mabrur, 2019). Sehingga lempung dapat digolongkan dalam akuiklud atau lapisan yang tidak dapat dilalui air dalam jumlah yang berarti, walaupun formasi tersebut mengandung air (Suharyadi, 1984). Dengan kata lain lempung bukan sebagai tempat menyimpan dan mengalirkan air tanah.

\section{Pasir Lempungan}

Pasir lempungan dapat diartikan sebagai batuan yang mayoritas terdiri dari material yang berukuran pasir $(1 / 8-1 / 2 \mathrm{~mm})$ dan memiliki kandungan material yang berukuran lempung (kurang dari 1/256 mm). Keberadaan lempung pada batuan atau lapisan pasir lempungan menjadikan permeabilitas batuan tersebut kecil. Oleh karena permeabilitasnya kecil, maka pasir lempungan juga dimasukan dalam akuiklud dan bukan sebagai penyimpan airtanah yang baik.

\section{Pasir}

Pasir merupakan ukuran dari material penyusun batuan yang memiliki ukuran 1/8-1/2 mm (Wentworth, 1922). Memiliki permeabilitas yang cukup tinggi (Mabrur, 2019). Berdasarkan sifat-sifat pasir tersebut, maka pasir dapat diinterpretasikan sebagai akuifer atau suatu lapisan/formasi geologi dimana formasi tersebut mengandung air dan didalam kondisi yang umum ditemui di lapangan memungkinkan air melalui formasi tersebut. Sehingga akuifer pada area penilitian ini diinterpretasikan berupa pasir.

\section{Penampang 3 Dimensi Akuifer}

Berdasarkan pendugaan geolistrik yang telah dilakukan, maka dapat diketahui bahwa ketebalan akuifer berkisar antara 10,9-18,7 m. Sedangkan kedalaman akuifer berkisar antara 34,5-50,2 m. Melihat dari kedalaman akuifer tersebut, maka air tidak dapat dambil dengan metoda sumur gali, tetapi dapat diambil dengan menggunakan metoda sumur bor.

Model 3 dimensi dari setiap lapisan yang ada dibuat untuk dapat lebih jelas dalam melihat posisi baik kedalaman dan ketebalan akuifer pada daerah penelitian. Penampang 3 Dimensi tersebut dihasilkan dari interpolasi 3 (tiga) titik pengukuran geolistrik. Hasil dari interpolasi yang berupa penampang 3 Dimensi dapat dilihat pada Gambar 4. 



\section{KESIMPULAN}

Berdasarkan hasil pendugaan geolistrik, maka diketahui di daerah penelitian terdapat 3 (tiga) lapisan batuan yaitu tanah (soil), lempung yang dikategorikan sebagai akuiklud, pasir lempungan yang dikategorikan sebagai akuiklud dan pasir yang dikategorikan sebagai akuifer. Berdasarkan pendugaan geolistrk yang telah dilakukan, maka dapat diketahui bahwa ketebalan akuifer berkisar antara 10,9 - 18,7 m. Sedangkan kedalaman akuifer berkisar antara 34,5-50,2 m. Sehingga untuk pengambilan air tanah diperlukan konstruksi sumur dalam untuk menembus akuifer dengan kedalaman lebih dari $35 \mathrm{~m}$.

\section{UCAPAN TERIMA KASIH}

Penulis mengucapkan terima kasih untuk Departemen Teknik Geologi, Fakultas Teknik, Universitas Diponegoro yang telah memfasilitasi dalam penelitian ini.

\section{DAFTAR PUSTAKA}

Amsyari, F., 1996. Membangun Lingkungan Sehat : Menyambut 50 Tahun Indonesia Merdeka. Surabaya: Airlangga University Press.

Das, B.M., 1985. Mekanika Tanah. Jakarta: Erlangga.

Hastuti, D., Sarwono, dan Muryani, C., 2017. Mitigasi, Kesiapsiagaan, dan Adaptasi Masyarakat Terhadap Bahaya Kekeringan, Kabupaten Grobogan (Implementasi Sebagai Modul Konstektual Pembelajaran Geografi SMA Kelas X Pokok Bahasan Mitigasi Bencana). Jurnal GeoEco, 3, hal.47-57.

Indarto, Wahyuningsih, S., Pudjojono, M., Ahmad, H., dan Yusron, A., 2014. Studi Pendahuluan Tentang Penerapan Metode Amba Bertingkat Untuk Analisis Kekeringan Hidrologi Pada 15 DAS di Wilayah Jawa Timur. Jurnal Agroteknologi, 8, hal.112-121.
Mabrur, M., 2019. Studi Korelasi Koefisien Permeabilitas Vertikal dan Permeabilitas Horizontal pada Tanah Lempung. Prosiding SEMDI, 3, hal.227-237.

Pemerintah Kabupaten Banyumas, 2009. Laporan Status Lingkungan Hidup Daerah Kabupaten Banyumas Tahun 2009. Banyumas: Pemerintah Kabupaten Banyumas.

Rejekiningrum, P., 2009. Peluang Pemanfaatan Air Tanah Untuk Keberlanjutan Sumber Daya Air. Jurnal Sumberdaya Lahan, 3, hal.85-96.

Santoso, I.S., Hardinsyah, Siregar, P. dan Pardede, S.O., 2011. Air Bagi Kesehatan. Jakarta: Centra Communications.

Savitri, E. dan Pramono, I.B., 2018. Identifikasi Dan Mitigasi Kerentanan Kekeringan DAS Moyo. Jurnal Penelitian dan Pengelolaan Daerah Aliran Sungai, 2, hal.173-187.

Setiono, D., Pudjihardjo, H., dan Hidajat, W.K., 2014. Penyelidikan Zona Akuifer Menggunakan Geolistrik Metode Schlumberger Di Sekitar Pantai Utara Kecamatan Kramat, Suradadi Dan Warureja Kabupaten Tegal, Jawa Tengah. Geological Engineering E-Journal, 6, hal.1-15.

Sudarsono, U., dan Hasibuan, G., 2011. Karakteristik Geologi Teknik Tanah Residu Batuan Sedimen Kuarter Bawah Daerah Kertajati, Majalengka, Jawa Barat. Jurnal Geologi Indonesia, 6, hal.177-189.

Suharyadi, 1984. Geohidrologi. Jurusan Teknik Geologi Yogyakarta: Fakultas Teknik Universitas Gajah Mada.

Wentworth, C.K., 1922. A Scale Of Grade And Class Terms For Clastic Sediments. The Journal of Geology, 30, hal.377-392.

Widarti, S., 2015. Pengaruh Laju Alir Terhadap Efisiensi Kolom Resin Penukar Kation Komersil dan Adsorpsi Ion Logam Berbeda Muatan. Jurnal Sigma-Mu, 7, hal.1-5. 